$\xi=-1$

\title{
Marketing Research as a Way to Increase Competitiveness of Railway Company and Forecasting of Demand for Transport
}

\author{
Viktoriia Yanovska $^{1 *}$, Olena Pylypenko ${ }^{1}$, Viktoriia Tvoronovych ${ }^{1}$, Anastasiia Bozhok ${ }^{1}$ \\ ${ }^{1}$ State University of Infrastructure and Technologies, Faculty of Management and Technology, Ukraine \\ *Corresponding author E-mail: v_yanovska@ukr.net
}

\begin{abstract}
Justification of management decisions for railway companies, under the conditions of the transport market liberalization, requires the search and collection of reliable information which is related with both the internal and external environment. Alongside, the need to provide competitiveness of the railways involves marketing research. The main objective of this paper is to determine the specific features of applying marketing tools for promotion of competitiveness and formation of the railway company's strategy. The dynamics of passenger traffic reflects the competitiveness of types of transport in terms of the ability to provide transport services for a better ratio of "price / quality". The performed researches confirm the presence of opposite tendencies in the long-distance and suburban connections, as well as specific factors of elasticity of demand for passenger transportation at a price. It is established that for the population (the consumer of transport services) the rate of tariffs for transportation is the determining factor of the attractiveness of the carrier in suburban transportation, and therefore it is the factor of its competitiveness, while the rate of tariffs is not the most significant factor in choosing a carrier in long distance transportation. There are subjective technical parameters of competitiveness which do not fit into the "price/ quality" system among the factors of choosing a carrier. During the choice of transportation, the consumer is guided by his own system of values which is not universal and leaves each transport company its "niche" for operation in the market as well as the opportunity to win its "own" consumer. Models of forecasting demand for passenger long-distance and suburban transportation by railway and automobile transport are proposed on the basis of forecast of macrofactors. The using of these models will allow railway and automobile companies to form their development strategies.
\end{abstract}

Keywords: competitiveness; forecasting; marketing research; passenger transportation; railway companies.

\section{Introduction}

Under current conditions of development, European integration is the main priority for Ukraine. Further development and deepening of relationships between Ukraine and the EU takes place on the principles of political association and economical integration, including transport industry as one of the key areas. According to the Article 368 of the Agreement about Association, the main objective of this cooperation is harmonization of the existing standards and policies in Ukraine with the EU policies and promotion of modernization and renovation of the Ukrainian transport industry $[1,2]$. Today, the Ministry of Infrastructure of Ukraine creates the legal framework in order to support the most urgent implementation of the EU norms and overcoming a range of problems that hinder development and reduce the competitiveness of railway transport, in general, and rail companies, in particular.

\section{Role of Marketing Research in Management of Railway Companies}

The main problems that affect the competitiveness of railway companies which are part of PJSC «Ukrzaliznytsia» include the absence of the mechanism for loss compensation in provision of social services and the existence of cross-subsidizing passenger transportation at the expense of freight transportation. This leads to an increase in freight railcar rates that are necessary to cover the expenses of passenger companies. As a result, the problem of aging of rolling stock and infrastructure becomes more complicated.

Losses from passenger transportation limit the possibility of purchasing new rolling stock in the necessary quantity and improving the quality of customer service according to the growing requirements. The rate of ageing of the rolling stock is significantly ahead of its upgrade. The amount of depreciation of railcars is more than $90 \%$, which two times exceeds the level adopted in the international practice [3]. The amount of purchases of new railcars is insufficient. This means that if the situation for passenger transport does not improve, freight railcar rates will increase more rapidly.

The aforementioned problems are taken into consideration in the updated National Transport Strategy by 2030 [4]. This document emphasizes the need of improving the mobility of citizens on the territory of the state and beyond, as well as sets the priorities for further development of transport industry on the part of passenger transportation. The development priorities, which are identified in the National Transport Strategy by 2030, determine the following key factors for the success of railway companies $[4,5]$ :

- liberalization of the market of transport services;

- creation of suburban railway companies;

- introduction of modern technologies and change of the outdated standards; 
- development of new high-speed interregional connections and connections with the EU countries;

- reduction of traditional long-distance passenger traffic and increase in passenger traffic carried by daytime and express trains;

- development of technologies for express (high-speed) passenger transportation in densely populated locations, creation of HUB-centers;

- development of multimodal transportation, organization of international traffic including different transport modes;

- improving the quality of transport services;

- implementation of the strategy of service;

- provision of the government order for socially significant passenger transportation in the regulated segment;

- transfer of non-core services for preparation of passenger railcars for the travel to outsourcing.

Implementation of development priorities of railway companies requires justification of managerial decisions on the basis of marketing research. Modern model of European integration development of railway transport in Ukraine suggests improvement of the planning process and taking of the marketing measures by all participants of the transportation process. In the report of the Ministry of Infrastructure of Ukraine about the results of implementation of the State Target Program for Railway Transport Reform for 20102019, the main tasks that are identified include the need to increase the competitiveness of railway transport in domestic and foreign markets of transport services [6].

In order to ensure the competitiveness of railway companies in the field of passenger transportation, it is necessary not only to offer quality services, but also to have information about who needs these services and for what purpose. Such information can be obtained by conducting marketing research of consumers and the competitive environment, as well as through analyzing marketing information. The strategy of increasing the competitiveness for railway passenger companies should be formed taking into account the results of marketing research that are obtained during the study of external and internal environment, analysis of transportation markets dynamics and demand for passenger transportation, segmentation analysis and development of a marketing mix for target groups of consumers, as well as short- and medium-term forecasting of passenger transportation.

\section{Related Works}

Numerous authors emphasize the locality and short-runtime of individual competitive advantages that can be potentially copied or surpassed by other competitors [7, 8 etc.]. Thus, the establishment of the degree of competitiveness for passenger transport should always be carried out for the specified period of time, for the specified executor (carrier) and for certain connection (destination), taking into account that the extent of competitive advantage of the carrier is influenced by strategic and tactical market changes that are not related with the company's activities (demand changes, migration flows, demographic shifts, natural phenomena, etc.). In Ukraine, in addition to the above factors, the annexation of the Autonomous Republic of the Crimea and military actions in the East of Ukraine influenced formation of passenger traffic.

It is known that the degree of the company's competitiveness can be determined in two ways:

1) performing direct assessment of the volume and dynamics of market activity (based on the definition of the term 'competitiveness' as the ability to withstand the competition);

2) carrying out complex comparative characteristics which reflects the degree of competitive advantages for aggregate indicators of the company in relation to aggregate indicators of the given company's competitors. For example, calculation of the complex indicator of the competitiveness for transport services can be performed. Competitiveness of the provided (or proposed) transport service is an expression of the competitiveness of the company; both categories are directly related.
In order to establish the degree of competitiveness for passenger transportation by various transport modes and types of rolling stock, it is necessary to compare the quality and value indicators of transport modes and vehicles, i.e. to contrast factors of competitiveness. Based on the content and method of calculating the complex indicator of the competitiveness of transport services, it is appropriate to divide these factors into three groups:

- normative factors (which provide for accordance of service with the approved Ukrainian and international norms and standards of quality, environmental and labor safety, norms for resource consumption, etc.);

- technical factors (that are characteristic of the technical and physical properties of the goods, functions of goods in the process of using; include assignment parameters, including classification, design, technical efficiency; ergonomic and aesthetic parameters); - economic factors (which include evaluation of expenses that are necessary for purchase and use of the service).

Calculation of the complex indicator of competitiveness has the following form:

$K=I_{H} \times \frac{I_{T}}{I_{E}}$,

where $K$-complex indicator of the competitiveness of the service; $I_{H}$ - group indicator of competitiveness according to normative parameters; $I_{T}$ - group indicator of competitiveness according to technical parameters; $I_{E}$ - group indicator of competitiveness according to economic parameters.

\section{Investigation of Carriers' Competitiveness}

\subsection{Dynamics of Passenger Traffic}

The dual nature of the category "competitiveness of the railway company" in the field of passenger transportation stems from the consumer's target of obtaining the transport service under a better correlation of «price / quality» and is reflected through the dynamics of the indicators of passenger traffic.

According to research of the information from the Ministry of Infrastructure of Ukraine in 2014-2017, passenger traffic surveys revealed a significant decrease in passenger traffic volumes in the long-distance connections (including direct transportation) between Donetsk and Prydniprovska railways as compared to 2013. Thus, the Donetsk railroad long-distance passenger traffic amounted only $13 \%$ in 2015 and totaled $15.6 \%$ in 2016 when contrasted to passenger traffic in 2013. Alongside, there was the average fall in long-distance passenger traffic performed by Ukrzaliznytsia, in general, at the rate of $65.7 \%$ in 2016 to 2013 (calculated according to [9]).

Results of research on the statistic information indicate that there are two contradictory trends in passenger traffic: the share of passenger traffic by suburban railway companies increased from $35.7 \%$ (in 2010) to $43.2 \%$ (in 2015) and to $45.9 \%$ (in 2016) of total volume of passenger traffic carried by suburban transport. By contrast, the share of passenger traffic carried by automobile companies (buses) in suburban connection in the same years decreases: from $64.1 \%$ in 2010 to $56.7 \%$ and to $53.8 \%$ accordingly in 2015 and 2016, calculated on the basis of [10]).

On the contrary, in the long-distance connection (including international transportation), the share of passenger traffic by railway companies is somewhat decreasing from $27.3 \%$ in 2010 to $23.5 \%$ in 2015 and to $24.6 \%$ in 2016. The share of passenger traffic carried by road transport in long-distance connection, conversely, is increasing - from $65.2 \%$ in 2010 to $72.9 \%$ in 2015 and to $70.9 \%$ in 2016. According to the data from the Ministry of Infrastructure of Ukraine in 2017, the share of passenger traffic by automobile transport was $38 \%$ of the total passenger turnover. As for intercity traffic, $65.8 \%$ of all passengers were carried by automobile 
transport, and $62.7 \%$ of all suburban passenger traffic was carried in by automobile transport (calculated according to [11]).

The revealed trends suggest that there are such tendencies: reduction of competitiveness for railway companies in long-distance passenger transportation (including international transportation), and increasing the competitiveness of railway carriers in suburban transportation.

\subsection{Influence of Price Factor on Degree of Competitive- ness}

Study of the rate of railway and automobile tariffs for passenger traffic in suburban and intercity connections suggests that the tariff rate is not the most important competitive advantage of automobile transport compared to intercity railways. The tariffs for automobile transport grew at a much faster rate $-136.4 \%$ against $106.4 \%$ in 2015 and almost at the same rate in $2016-103.4 \%$ against $101.4 \%$ in intercity railway connection [10, p. 81-83].

At the same time, the growth of tariffs for suburban railway connection was even higher than the growth of tariffs for suburban automobile transportation [10, p. 81-83]. However, in absolute measurement, the tariffs of railway companies for suburban transportation are significantly lower. In addition, experts say about the unjustified overvaluation of automobile carriers' tariffs: it is considered that the economically justified tariff for suburban automobile transportation, as of February 2017, is 0,6 UAH per kilometer (or $60 \mathrm{UAH}$ per $100 \mathrm{~km}$ ), but in reality some carriers establish the travel cost from 85 to $120 \mathrm{UAH}$ per $100 \mathrm{~km}$.

Inversely, tariffs for passenger railway transportation in suburban connection depend on the distance of transportation and make up (for a full ticket): South-Western railway - from UAH 8 for $1 \mathrm{~km}$ to UAH 20 for $260 \mathrm{~km}, 12 \mathrm{UAH}$ for $100 \mathrm{~km}$ [12]; Lviv railway from UAH 8 for $1 \mathrm{~km}$ to UAH 45 for $230 \mathrm{~km}, 25 \mathrm{UAH}$ for 100 $\mathrm{km}$ [13]; Odessa railway - from 8.6 UAH per $1 \mathrm{~km}$ to $43.6 \mathrm{UAH}$ for $320 \mathrm{~km}$ of transportation; $100 \mathrm{~km}-23 \mathrm{UAH}$ [14]; Prydniprovska railway $-8 \mathrm{UAH}$ for $1-5 \mathrm{~km}$ and $70 \mathrm{UAH}-$ for $200 \mathrm{~km}$ distances; $100 \mathrm{~km}$ - 32 UAH [15].
Other railways do not represent transportation tariffs on their official web-pages because each of them is a regional branch of PJSC "Ukrzaliznytsia". This allows us to hope that their tariff policy is similar and is formed on the basis of the common principles.

Thus, it follows from the above that for the population, i.e. the consumer of transport services in suburban transportation, the rate of tariffs for transportation is the determining factor of the attractiveness of the carrier and therefore it is the factor of its competitiveness. The tariff rate is considerably lower on railway transport. Such conclusions are fully consistent with the laws of supply and demand and the factors of the elasticity of demand for the price. Because the consumers (the population) is carries out the longdistance (including international and intercity) transportation not very often (not every day), then expenses on the long-distance transportation either take a small part in the budget of the consumer, or are official trips and fall on the expenses of employers. But for the population of the satellites cities of the megacities which has the need to use the services of suburban transportation companies daily for trips to work, the share of transport costs in their budget will be significantly higher. Therefore, these consumers try to optimize their cost and, as they have more time to make decisions, choose the cheapest trips.

\subsection{Estimation of the Complex Index of Competitiveness of Transport Services}

Factor of the lowest prices (tariffs) does not always "work" for long-distance passenger traffic. Shaping the consumer's choice, there enters a requirement to install other factors into the system "money / quality". These new factors determine the carrier's competitiveness.

In order to establish the influence of the factors, the most popular current passenger connection Kyiv-Odessa was chosen (approximate distance $-477 \mathrm{~km}$ as the crow flies); price variants and conditions of travel are presented in the table. 1.

Table 1: Comparison of quality for transport service along the route

\begin{tabular}{|c|c|c|c|c|c|c|c|}
\hline \multirow[b]{2}{*}{ Indicators } & \multirow[b]{2}{*}{$\begin{array}{l}\text { Reference } \\
\text { carrier }\end{array}$} & \multicolumn{6}{|c|}{ Number of the train або name of the carrier } \\
\hline & & $\begin{array}{c}\text { Express train } \\
\text { № } 148 \mathrm{~K} \text {, sleeping } \\
\text { car }\end{array}$ & $\begin{array}{l}\text { № } 223 \text { special } \\
\text { train }\end{array}$ & $\begin{array}{c}\text { № } 105 \mathrm{~K} \\
\text { «Chernomorets» }\end{array}$ & № 763Л Intercity+ & LLC «Gyuncel» & AutoLux \\
\hline Time on the road & $\min$ & $13 \mathrm{hr} 22 \mathrm{~min}$. & $\approx 10 \mathrm{hr}$ & $\approx 9 \mathrm{hr}$ & $7 \mathrm{hr} 11 \mathrm{~min}$ & $6 \mathrm{hr} 20 \mathrm{~min}$ & $6 \mathrm{hr} 35 \mathrm{~min}$ \\
\hline $\begin{array}{c}\text { Time of depature - } \\
\text { arrival }\end{array}$ & - & $15.49-05.11$ & $07.38-17.41$ & $21.15-06.18$ & $16.35-23.46$ & Several t & nes a day \\
\hline \multirow{2}{*}{$\begin{array}{l}\text { Services included in } \\
\text { the price }\end{array}$} & \multirow[b]{2}{*}{$\max$} & \multirow[b]{2}{*}{ Bed linen, tea } & \multirow{2}{*}{\multicolumn{2}{|c|}{ Bed linen, tea, conditioner }} & \multirow{2}{*}{$\begin{array}{l}\text { Conditioner, place } \\
\text { for luggage }\end{array}$} & \multicolumn{2}{|c|}{$\begin{array}{l}\text { Air conditioning; comfortable and } \\
\text { functional armchairs }\end{array}$} \\
\hline & & & & & & - & $\begin{array}{c}\text { VIP - coffee, tea, } \\
\text { TV, Wi-Fi, tablet, } \\
\text { biotoilets }\end{array}$ \\
\hline $\begin{array}{c}\text { Services (goods), } \\
\text { available for } \\
\text { additional fee }\end{array}$ & $\max$ & \multicolumn{4}{|c|}{ Buffet, beverages, information } & \multicolumn{2}{|c|}{-} \\
\hline
\end{tabular}

All carriers, with the exception of the latter, declare certain restrictions for return and exchange of ticket cost (partial or full retention of ticket costs due to delay of the bus trip or late return is possible in less than 24 hours before the departure). As a result, these restrictions weaken the compliance of the transport service to economical parameters of competitiveness.

In table 1 , indicators of the reference carrier demonstrate the most attractive price offer and provide the maximum available amount of additional free of charge and reimbursable services.

Having compared the specified individual transport services enroute "Kyiv-Odessa" in three parametric indicators groups of competitiveness we can state that:
- the normative parameters are being complied with by all carriers However, considering the factor of environmental friendliness and safety of transportation, this normative parametric indicator is higher for railway transport and railway companies. The level of emissions as a result of operation of railway transport is lower when compared with other modes of transport [16]. In addition, railway transport is a much safer transport mode. According to the data of the World Bank, the number of fatalities on railway transport is 14 times lower than on automobile transport [17];

- according to technical parameters, the best transport services are provided by VIP class buses; hence, the company AutoLux is the best carrier in terms of technical parameters; 
- according to economic parameters, the cheapest way of transportation is fast train sleeping car transportation on the train number $148 \mathrm{~K}$, so the services of the railway carrier are the most outstanding;

- the integral indicator of competitiveness proved to be the highest for bus transportation of AutoLux by VIP class buses, as it corresponds to the best "price/quality" ratio.

However, it should be noted, that a survey of 144 passengers conducted through questionnaires in the framework of the study of the competitiveness of the carriers revealed that the choice of carrier and transport mode is not always made based on the passenger's preferences. In the opinion of the majority of passengers, in a large number of long-distance connections, there is a limited supply of low-cost convenient transportation, including sleeping car railway transportation. This allows the market be classified as a market with a limited supply given a sufficient (competitive) number of carriers.

There is another trend. Among the factors that contribute to the choice of the carrier there are subjective parameters that do not fit into the "price / quality" system and can be classified as technical parameters of competitiveness. In mode choice for transportation, the consumers are guided by their own system of values which is not universal. Thus, during the research process, it was not possible to establish the optimal "departure time-arrival time" parameter, since this parameter depends on the purpose of the trip, is often incurred by subjective criteria, and, in the end, affects the mode choice. Then, the mode choice may not always be in line with the optimal "price/quality" ratio of transportation. This leaves each transport company its "niche" for operation in the market of transport services and the opportunity to win their "own" consumer of transport services.

\section{Forecast of the Demand for Passenger Transportation}

\subsection{Features of the Forecasting Process}

Formation of a competitive strategy for railway companies in the field of passenger transportation requires definition of the target market, identification of dynamics and forecasting of development trends. For railway companies, the forecasted demand for passenger transportation is transformed into potential revenue. In addition, demand forecasting allows determine the need for rolling stock, personnel, necessary investment, and development priorities. The specificity of forecasting demand for passenger transportation is obligatory consideration of both macroeconomic (even global) trends and factors of the local level. Forecast of the state of the economy as a whole is based on the forecast of the socio-economic indicators. For the forecast of the demand for railway carriers' services the following must be taken into account: dynamics of prices for transportation; technical and technological characteristics of the rolling stock; qualification of the personnel; dealer network or other agent network; and income of the population.

Moreover, it is necessary to regard the social nature of transportation, the state policy in the field of subsidization of the regulated segment of transportation (possible monetization of benefits), their specific features (non-alternative transportation, low price elasticity of demand for long-distance transportation, as well as high elasticity of demand for passenger traffic in suburban connection). General forecast of the number of passengers transported by railway takes into account the following macroeconomic trends:

- forecast of the population of Ukraine in 2018-2020 (according to the UN forecast) [18];

- forecast of the real income of the population according to the IMF assessment [19];

- GDP statistics of the population and the real income of the population [20].
Construction of the model of the forecasted volume of passenger transportation in long-distance and suburban connection is based on extrapolation of the revealed tendencies of macro factors' (number, volume of income) development and consideration of the main methodological provisions while interviewing experts in the light of the results of marketing research.

Collective evaluation by the experts, supported by experimental calculations, is very important when constructing equations of econometric models. Errors can thus be minimized. In the process of econometric modelling, expert estimation methods and their modifications should be used to determine the quantity and structure of economic indicators and in order to identify the main dependencies between the indicators. As the experts, highly qualified planners and scholarly economists with practical experience were involved. Demand for transportation is an indicator that reflects the dependence of the number of passengers transported on the real income $\left(x_{1}\right)$ and population $\left(x_{2}\right)$.

\subsection{Forecast Models of Demand for Long-Distance Transport}

Forecast model of the demand for long distance railway passenger transportation is described by the formula:

$y=-0.51445+0.00443 \cdot x_{1}+1.14513 \cdot x_{2}, R^{2}=0.90381$.

The demand model for intercity automobile passenger transportation takes the form:

$y=-0.52399+0.0005 \cdot x_{1}+3.10017 \cdot x_{2}, R^{2}=0.98706$.

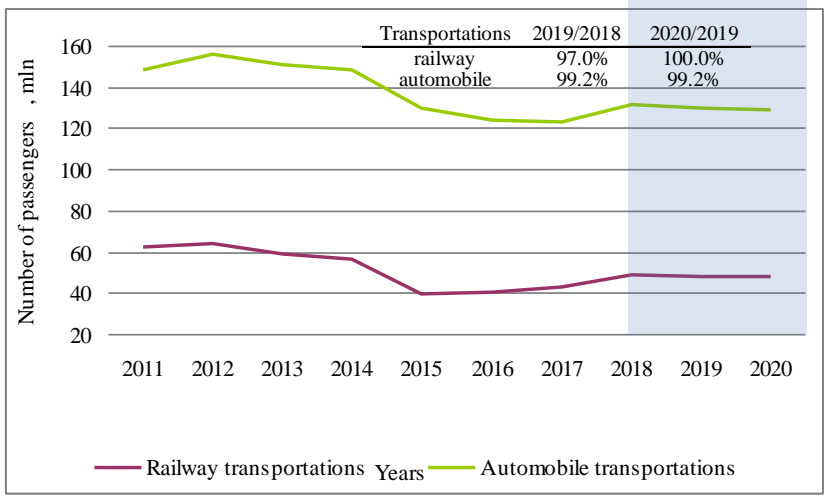

Fig. 1: Demand for long-distance passenger traffic by statistical data for 2011-2017 and forecasted data for 2018-2020

The demand model for long-distance passenger transportation reflects:

- decreasing nature of the volume of transportation according to the number of passengers;

- overwhelming dependence of the volume of transportation on demographic changes; at the same time, traffic volume is least dependent on the dynamics of income;

- reduction of the population (negative population growth) caused a drop in the demand for transportation in 2014-2016.

- in the forecasted period, the demand growth by $3 \%$ for railway transportation against $0.8 \%$ increase in automobile passenger transportation.

\subsection{Forecast Models of Demand for Suburban Trans- portation}

The demand model for suburban railway transportation has the form: 


$$
y=0.38164+0.00112 \cdot x_{1}+8.04937 \cdot x_{2}, R^{2}=0.99906 .
$$

The model of demand for suburban automobile transportation is described by the dependence:

$$
y=5.43044+0.03872 \cdot x_{1}+12.77994 \cdot x_{2}, R^{2}=0.94915 .
$$

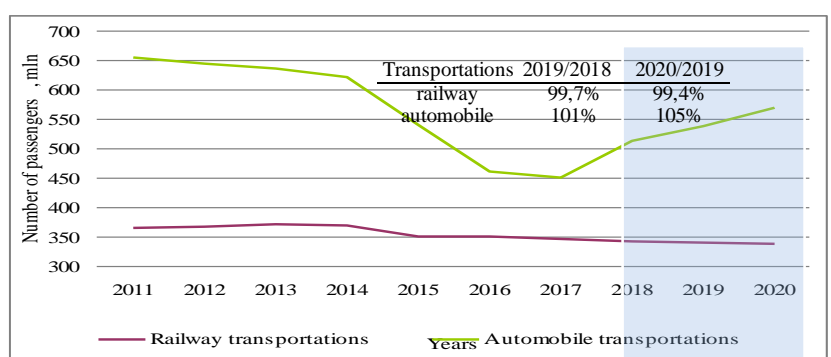

Fig. 2: Demand for suburban transportation by statistical data for 20112017 and forecasted data for 2018-2020

The expected demand for suburban railway transportation also depends more on the population than on the income of population. In the coming years, with the current demographic situation, the volume of transportation tends to decrease by about $0.3 \%$ per year for railway transport, and an annual growth of about $5 \%$ is expected for automobile transport.

\subsection{Forecast Models of Passenger Traffic}

The forecast model of passenger traffic on railway transport is described by the formula:

$$
y=-0.42388+0.0021 \cdot x_{1}+0.9935 \cdot x_{2}, R^{2}=0.95532 \text {. }
$$

The forecast model of passenger traffic on automobile transport is described by the formula:

$$
y=-0.42414+0.003 \cdot x_{1}+1.01426 \cdot x_{2}, R^{2}=0.95233 \text {. }
$$

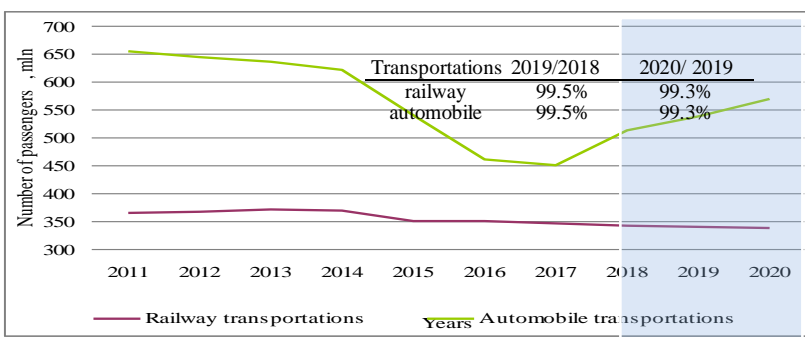

Fig. 3: Passenger traffic of rail and road transport by statistical data for 2011-2017 and forecasted data for 2018-2020

The forecasted data indicates that the passenger traffic for railway and automobile transport is characterized by a certain growth until 2018, and from 2018 on, a slight but steady decline is observed.

\section{Conclusion}

According to the results of the marketing research, we can argue that the passenger transport market has a rather complex structure and can be characterized, to the greatest extent, as the monopolistic competition. This market structure promotes the provision of the most diverse services with different tariff rates. This allows sellers to avoid direct price competition and "diverge" across different market segments. However, due to the current technical condition of the rolling stock of railway companies, the emergence of successful competitors (those carriers that employ comfortable buses in passenger transportation) can lead to further loss of com- petitive positions in the long-distance transport sector. Railway companies should urgently pay attention to the possibility of improving the technical condition of passenger railcars and increasing the volume of transport services in the segment of low-cost transportation. In the medium term, automobile and railway companies will continue playing a key role in meeting the demand for transportation, including passenger transportation in cities. Carriers will compete with each other. Price reduction of suburban railways compared with automobile vehicles is an advantage of railways. But reduction of suburban trains and uncomfortable traffic flow will increase the volume of road transportation. Consequently, the main components of the medium-term program of action should be the measures to ensure the stable and efficient operation of railway companies by improving the quality of services and maintaining a relatively low level of transport costs.

\section{References}

[1] "Ievropeiska intehratsiia", Ministerstvo infrastruktury Ukrainy, available online: https://mtu.gov.ua/timeline/Evrointegraciya.html

[2]"Uhoda pro asotsiatsiiu mizh Ukrainoiu, z odniiei storony, ta Yevropeiskym Soiuzom, Yevropeiskym spivtovarystvom $\mathrm{z}$ atomnoi enerhii i yikhnimy derzhavamy-chlenamy, z inshoi storony”, Verkhovna Rada Ukrainy, available

http://zakon5.rada.gov.ua/laws/show/984_011/print1509993267006954

[3] Hudkova V.P., Yarmolitska O.V. (2016) "Innovatsiino-investytsiine vidtvorennia osnovnykh vyrobnychykh zasobiv pidpryiemstv zaliznychnoho transportu”, Ekonomichnyi forum, № 1, s.: 129-137.

[4] "Natsionalna transportna stratehiia Ukrainy do 2030", Ministerstvo infrastruktury Ukrainy, 2017, s. 42.

[5] Eitutis H, Krivopishyn O, Fedorko I (2016) "Teoretychni i praktychni osnovy reformuvannia zaliznychnoho transportu Ukrainy", Monohrafiia, s.: $8-9$.

[6] "Zvit pro rezultaty realizatsii Derzhavnoi prohramy reformuvannia zaliznychnoho transportu Ukrainy", Ministerstvo infrastruktury Ukrainy, available online: https://mtu.gov.ua/news/98.html

[7] Ashmarina S, Zotova A (2016) "The system of marketing information management: development, assessment, improvement", Economic Annals-XXI: Vol. 160 (7-8), pp: 51-55.

[8] Branda A.F., Lala V., Gopalakrishna P. (2018) “The marketing analytics orientation (MAO) of firms: identifying factors that create highly analytical marketing practices", Journal of Marketing Analytics: June, available online: https://link.springer.com/content/pdf/10.1057/s41270018-0036-8.pdf

[9] Statystychni dani pro Ukrainski zaliznytsi, Ministerstvo infrastruktury Ukrainy, available https://mtu.gov.ua/content/statistichnidaniproukrainskizaliznici.html

[10] Transport i zviazok Ukrainy: 2016, Statystychnyi zbirnyk, Derzhavna sluzhba statystyky Ukrainy, K., 2017, s. 175.

[11] Statystychni dani po haluzi avtomobilnoho transportu, Ministerstvo infrastruktury Ukrainy, available online: https://mtu.gov.ua/content/statistichni-dani-po-galuzi-avtomobilnogotransportu.html

[12] Taryfy, Pivdenno-Zakhidna zaliznytsia, available online: http://swrailway.gov.ua/timetable/eltrain/attention/

[13] Taryfy na proizd u prymiskomu spoluchenni, Lvivska zaliznytsia available online: http://railway.lviv.ua/schedule/fares/

[14] Tablytsia vartosti proizdu pasazhyriv u prymiskomu spoluchenni po rehionalnii filii (stanom na 29.12.2017 r.), Odeska zaliznytsia available online: http://odz.gov.ua/suburban/value.php

[15] Taryfy na prymiski poizdy $\mathrm{z} 06.05 .2017$ r., Rehionalna filiia «Prydniprovska zaliznytsia»PAT «Ukrzaliznytsia» available online: https://dp.uz.gov.ua/ukr/tarifu_pp

[16] IEA-UIC Energy and CO2 Railway Handbook (2017), p. 120.

[17] Sustainable Mobility for All (2017), Global Mobility Report 2017: Tracking Sector Performance, The World Bank, Washington, DC, USA, p. 107.

[18] World Population Prospects (2017), The 2017 Revision, "Key Findings and Advance Tables", United Nations Department of Economic and Social Affairs/Population Division, p. 53.

[19] World Economic Outlook (2018) "International Monetary Fund", April, available http://www.imf.org/external/datamapper/datasets/WEO/1

[20] Ukraina u tsyfrakh 2016: Statystychnyi shchorichnyk. Derzhavna sluzhba statystyky Ukrainy, K., 2017, s. 240. 